\title{
Article \\ Small Reduced Graphene Oxides for Highly Efficient Oxygen Reduction Catalysts
}

\author{
Su-Jeong Bak ${ }^{1,2, \dagger}$, Sun-I Kim ${ }^{1,+}$, Su-yeong Lim ${ }^{1,2}$, Taehyo Kim ${ }^{1}$, Se-Hun Kwon ${ }^{2, *(D)}$ and Duck Hyun Lee ${ }^{1, *(\mathbb{D})}$ \\ 1 Green Materials and Processes R\&D Group, Korea Institute of Industrial Technology, Ulsan 44413, Korea; \\ baksj@kitech.re.kr (S.-J.B.); sunikim@kitech.re.kr (S.-I.K.); swimmingly@kitech.re.kr (S.-y.L.); \\ thkim0215@kitech.re.kr (T.K.) \\ 2 Department of Materials Science \& Engineering, Pusan National University, Busan 46241, Korea \\ * Correspondence: sehun@pusan.ac.kr (S.-H.K.); dulee@kitech.re.kr (D.H.L.); Tel.: +82-51-3775 (S.-H.K.); \\ +82-52-980-6709 (D.H.L.) \\ + Authors contributed equally to this work.
}

check for updates

Citation: Bak, S.-J.; Kim, S.-I.; Lim, S.-y.; Kim, T.; Kwon, S.-H.; Lee, D.H. Small Reduced Graphene Oxides for Highly Efficient Oxygen Reduction Catalysts. Int. J. Mol. Sci. 2021, 22, 12300. https://doi.org/10.3390/ ijms222212300

Academic Editor: Mihai V. Putz

Received: 20 October 2021

Accepted: 12 November 2021

Published: 14 November 2021

Publisher's Note: MDPI stays neutral with regard to jurisdictional claims in published maps and institutional affiliations.

Copyright: (C) 2021 by the authors Licensee MDPI, Basel, Switzerland. This article is an open access article distributed under the terms and conditions of the Creative Commons Attribution (CC BY) license (https:/ / creativecommons.org/licenses/by/ $4.0 /)$.

\begin{abstract}
We demonstrated highly efficient oxygen reduction catalysts composed of uniform $\mathrm{Pt}$ nanoparticles on small, reduced graphene oxides (srGO). The reduced graphene oxide (rGO) size was controlled by applying ultrasonication, and the resultant srGO enabled the morphological control of the Pt nanoparticles. The prepared catalysts provided efficient surface reactions and exhibited large surface areas and high metal dispersions. The resulting Pt/srGO samples exhibited excellent oxygen reduction performance and high stability over 1000 cycles of accelerated durability tests, especially the sample treated with $2 \mathrm{~h}$ of sonication. Detailed investigations of the structural and electrochemical properties of the resulting catalysts suggested that both the chemical functionality and electrical conductivity of these samples greatly influence their enhanced oxygen reduction efficiency.
\end{abstract}

Keywords: oxygen reduction reaction; proton exchange membrane fuel cell; graphene; Pt catalyst

\section{Introduction}

Fuel cells are an essential component of highly efficient and clean energy-production technologies. In particular, proton-exchange membrane fuel cells (PEMFCs) have shown great potential for power generation in stationary, mobile, and transportation applications owing to their low temperature, low emissions, rapid start-up time, energy efficiency, and power density [1-3]. The cathodic oxygen reduction reaction (ORR) is the rate-limiting reaction step in PEMFCs. Pt has been used as an ORR catalyst for over a decade because of its high catalytic activity [4], and its high cost has been combatted by the use of carbon black (CB), which reduces the required amount of Pt and enhances the stability of PEMFC active materials. However, $\mathrm{CB}$ has been shown to have low catalytic durability because it easily corrodes under an oxygen atmosphere $[1,3,5]$. To improve the long-term durability of PEMFC catalysts, carbon nanomaterials such as carbon nanotubes (CNTs), nanofibers, and graphene have been widely studied as support materials [1,6-8]. Graphene has attracted significant attention as a promising catalyst support owing to its unique 2-D structure, high conductivity, and large surface area [9-14]. In particular, graphene oxide (GO) is a promising support material that can serve as an electrocatalyst for PEMFCs owing to its abundant surface functional groups, which are chemically active sites that can be used for catalytic reactions and also act as anchoring sites for metal nanoparticles. However, excessive amounts of oxygen-containing functional groups can reduce the electrical conductivity and electrochemical stability of these systems, making them susceptible to chemical oxidation and decreasing their long-term durability [1,15-19]. Of all graphene-related materials, the most widely available and commonly used is reduced GO (rGO). The surface oxygen-containing groups located on the corrugated graphene layers of this material facilitate exfoliation, and its excellent dispersion of metal nanoparticles with a narrow range of sizes allows for its wide application [19-21]. 
Efficient ORR activity and durability can be achieved by combining the large surface area of a catalyst and the mass transfer of reactants on its surface, which is controlled by the morphology of the catalyst [22-24]. Therefore, the morphology of the catalyst is the main parameter that can significantly affect catalytic activity, selectivity, and stability. Several studies have shown that smaller catalyst supports result in higher conversions and yields for the ORR [25-28]. This is because the small sizes of these catalysts result in efficient surface reactions, due to their large surface areas, high metal dispersions, and minimal internal diffusion effects. Therefore, the size of the support and the interactions between the metal and support make an important contribution to maximizing the activity and stability of such catalysts. Herein, we report highly efficient oxygen reduction catalysts composed of uniform Pt nanoparticles on small rGO (srGO). Ultrasonication is used with varying times to control the rGO size, and the srGO enable the morphological control of the $\mathrm{Pt}$ nanoparticles. Consequently, the performance and stability of the $\mathrm{Pt} / \mathrm{srGO}$ samples are enhanced compared to those of $\mathrm{Pt} / \mathrm{rGO}$ and $\mathrm{Pt} / \mathrm{CB}$ in an acidic medium. A detailed investigation of the structural and electrochemical proper-ties of these catalysts was conducted to examine the impact of their chemical functionalities and electrical conductivities.

\section{Results and Discussion}

Figure 1 shows the synthetic procedure of $\mathrm{Pt} / \mathrm{srGO}$. Samples of rGO were mixed with $\mathrm{HCl}$ and treated via ultrasonication for 1,2, or $3 \mathrm{~h}$, and strong sonication was used to break the weak carbon bonds and reduce the size of rGO. Specifically, rGO was dispersed in an acidic solution to weaken the bonds, and then a physical external force was applied to remove the portions of carbon bonds where the bonding force was weak.

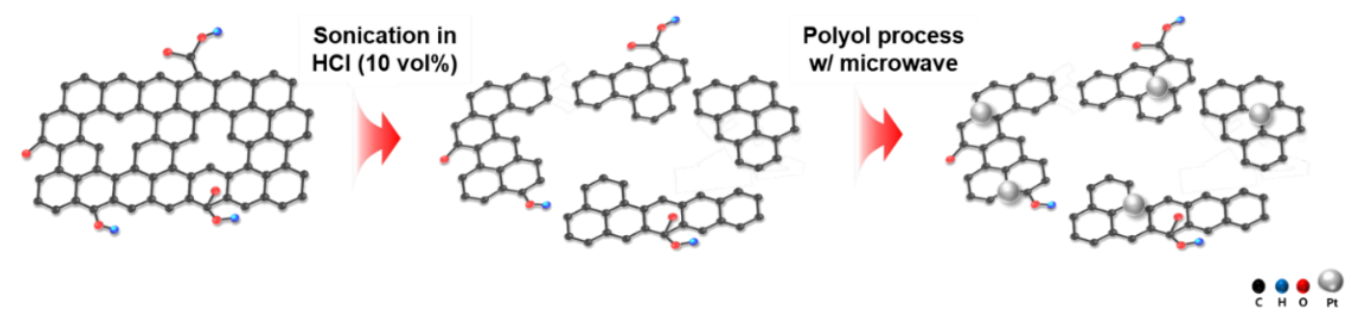

Figure 1. Schematic illustration of the synthesis of $\mathrm{Pt} / \mathrm{srGO}$.

The morphologies of the $\mathrm{rGO}$ and srGO supports were analyzed via a scanning electron microscope (SEM) (Figure 2a-d) and transmission electron microscopy (TEM) (Figure 2e-h). The TEM and SEM images indicated that the change in graphene size depended on the sonication time, from 1 to $3 \mathrm{~h}$. It was confirmed that the size of rGO decreased as the sonication time increased and that graphene sheets reduced from 6.6 to $1.2 \mu \mathrm{m}$. The morphologies of the rGO and srGO supports were analyzed via scanning electron microscopy (SEM) (Figure 2a-d) and transmission electron microscopy (TEM) (Figure 2e-h). The TEM and SEM images indicated that the change in the graphene size depended on the sonication time, which ranged from 1 to $3 \mathrm{~h}$. It was confirmed that the size of $\mathrm{rGO}$ decreased as the sonication time increased and that graphene sheets were reduced from 6.6 to $1.2 \mu \mathrm{m}$ in diameter. Graphene that was exfoliated and broken down through the physical sonication process also decreased in size. Brunauer-Emmett-Teller (BET) analysis was performed to examine the changes in the specific surface areas and pore volumes of rGO and srGO, and the results confirmed that the specific surface area and pore volume gradually increased as the sonication time increased (Table 1). 
(a)

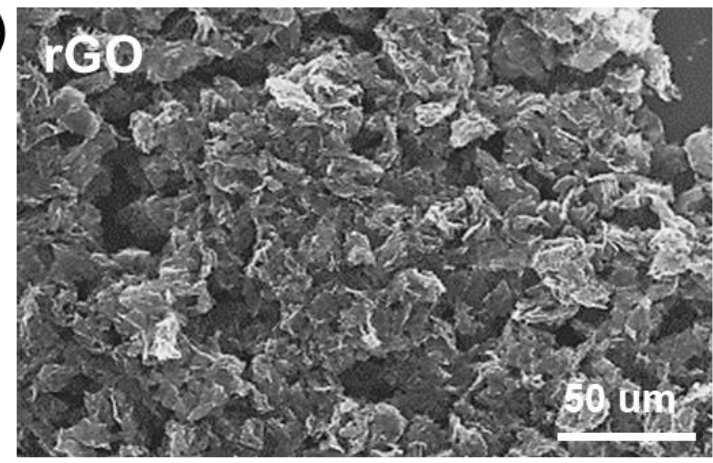

(b)

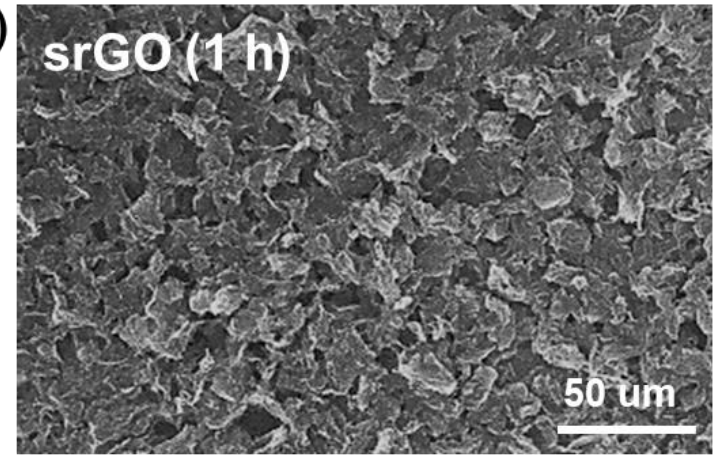

(c)

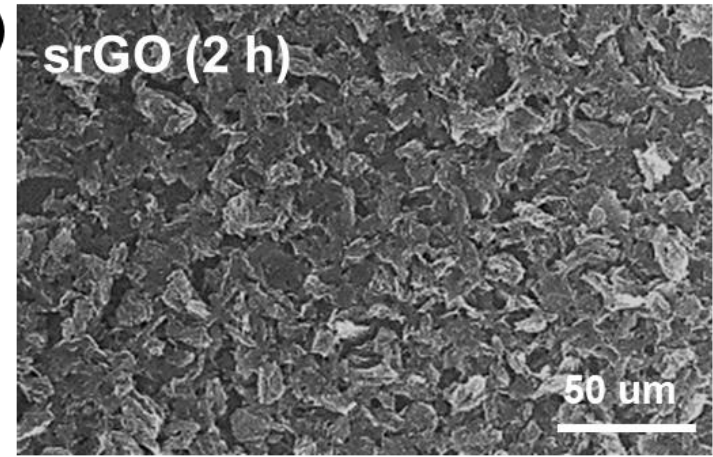

(d)

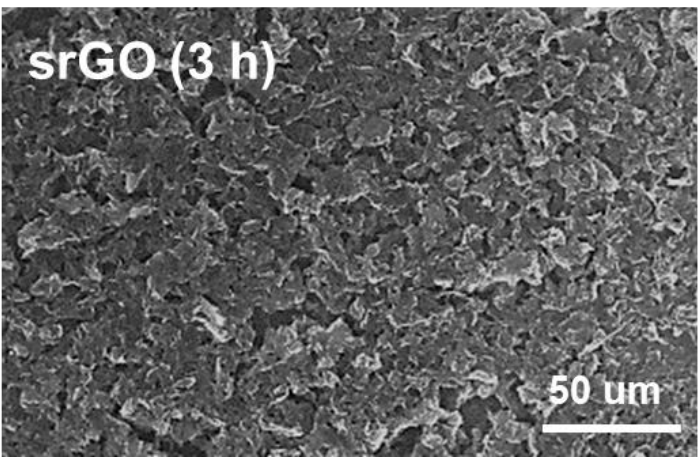

(e)

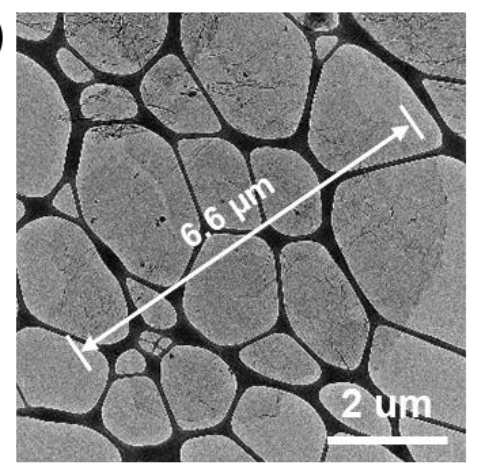

(f)

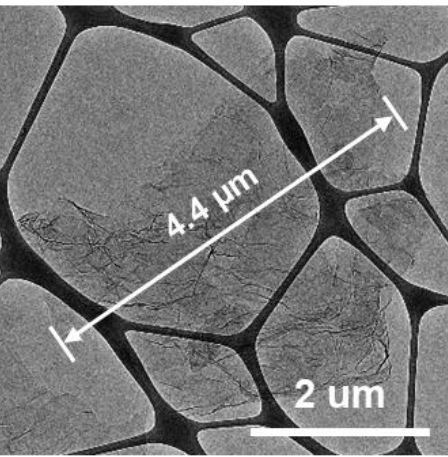

(g)

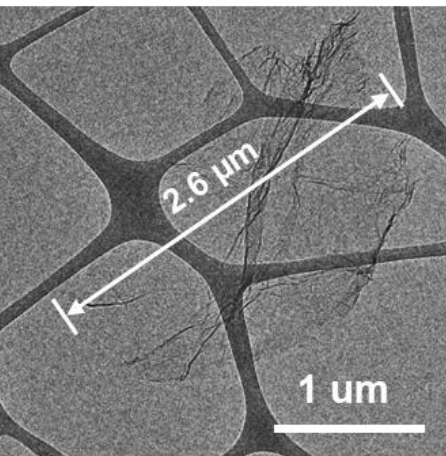

(h)

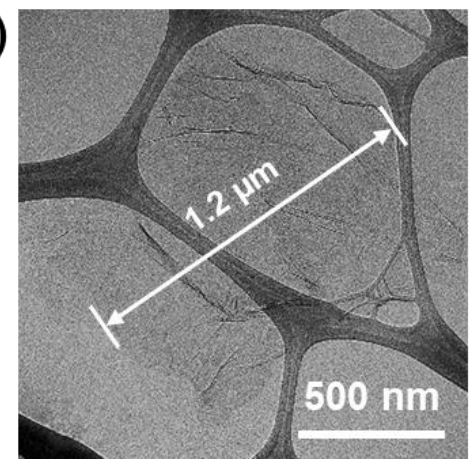

Figure 2. FE-SEM and TEM images of $(\mathbf{a}, \mathbf{e}) \mathrm{rGO},(\mathbf{b}, \mathbf{f}) \operatorname{srGO}(1 \mathbf{h}),(\mathbf{c}, \mathbf{g}) \operatorname{srGO}(2 \mathbf{h})$, and $(\mathbf{d}, \mathbf{h}) \operatorname{srGO}$ (3 h).

Table 1. BET surface area, pore volume, and pore size of rGO and srGO.

\begin{tabular}{cccc}
\hline Sample & SBET $\left(\mathbf{m}^{\mathbf{2}} \mathbf{/ g}\right)$ & $\begin{array}{c}\text { Pore Volume } \\
\left(\mathbf{c m}^{\mathbf{3}} \mathbf{g}\right)\end{array}$ & Pore Size (nm) \\
\hline rGO & 372.9 & 1.36 & 14.4 \\
srGO (1 h) & 402.7 & 1.43 & 14.1 \\
srGO (2 h) & 427.0 & 1.52 & 13.9 \\
srGO (3 h) & 441.0 & 1.57 & 14.3 \\
\hline
\end{tabular}


The ratio of defects on the rGO sample surfaces based on the sonication time was confirmed by Raman spectroscopy, as shown in Figure 3a. The G and D bands of the rGO Raman spectrum are located very close to each other, at approximately 1589 and $1334 \mathrm{~cm}^{-1}$, respectively. The $\mathrm{G}$ band resulted from the vibrational mode of adjacent carbon atoms in the hexagonal structure moving in opposite directions. The D band exhibited crystalline defects that formed during the oxidation and exfoliation of the graphite. The D-band intensity $\left(\mathrm{I}_{\mathrm{D}}\right) / \mathrm{G}$-band intensity $\left(\mathrm{I}_{\mathrm{G}}\right)$ ratio is a numerical value that is utilized to quantitatively compare the amounts of carbon crystals and defects $[29,30]$. The Raman spectra confirmed that $\mathrm{I}_{\mathrm{D}} / \mathrm{I}_{\mathrm{G}}$ increased with sonication time; this is because the $\mathrm{D}$ peak increases with the number of dangling defects. The larger the $\mathrm{I}_{\mathrm{D}} / \mathrm{I}_{\mathrm{G}}$ ratio, the more defects generated during the sonication process. Determining the $\mathrm{I}_{\mathrm{D}} / \mathrm{I}_{\mathrm{G}}$ value of $\mathrm{rGO}$ is an important factor in this process because a sufficient number of defects do not occur if the $\mathrm{I}_{\mathrm{D}} / \mathrm{I}_{\mathrm{G}}$ value of $\mathrm{rGO}$ is too small; therefore, the resulting sample would not have a sufficiently small size nor specific area. If the $\mathrm{I}_{\mathrm{D}} / \mathrm{I}_{\mathrm{G}}$ value of $\mathrm{rGO}$ is too large, excessive defects occur on the graphene surface, thereby reducing the crystallinity of graphene. The conductivity of rGO is also reduced under this condition, which inhibits sufficient electron transfer and greatly reduces the efficiency of the catalyst.
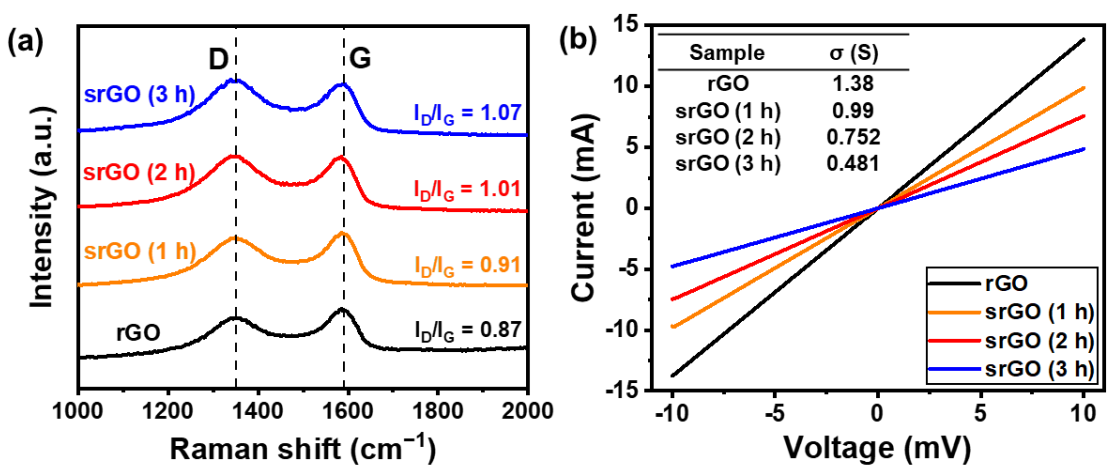

Figure 3. (a) Raman spectra and (b) representative IV curves of rGO, srGO (1 h), srGO (2 h), and $\operatorname{srGO}(3 \mathrm{~h})$.

X-ray photoelectron spectroscopy (XPS) analysis was performed to observe the changes occurring in the surface functional groups as a result of sonication (see Figure S1 and Table 2). The rGO C1s signal has three components corresponding to $\mathrm{C}-\mathrm{C}(284.5 \mathrm{eV}), \mathrm{C}-\mathrm{O}$ $(286.6 \mathrm{eV})$, and $\mathrm{C}=\mathrm{O}(288.5 \mathrm{eV})$ functional groups [31]. The $\mathrm{I}_{\mathrm{C}-\mathrm{O}} / \mathrm{I}_{\mathrm{C}-\mathrm{C}}$ ratio decreased after $3 \mathrm{~h}$ of ultrasonication because of an increase in the surface area and a decrease in the rGO particle size. Oxygen functional groups were introduced into the graphene basal and edge planes during the chemical exfoliation process [32]. Therefore, as the size of rGO decreases, the surface area and number of functional groups of rGO increase. Figure $3 b$ shows the electrical characterization of these samples achieved using a source measure unit (SMU), which obtains current (I)-voltage (V) curves. We found that the electrical conductance of rGO decreased as the sonication time increased from 1 to $3 \mathrm{~h}$. It is well known that graphene has a high in-plane electrical conductance; however, it also has a high contact resistance. As the size of srGO decreased, the contact resistance of bulk rGO increased. Therefore, the electrical conductivity of srGO decreased with increasing sonication time.

Table 2. C/O ratios of rGO and srGO calculated from XPS data.

\begin{tabular}{cccc}
\hline Sample & C Bonding & O Bonding & C/O Ratio \\
\hline rGO & $93.33 \%$ & $6.66 \%$ & 14.01 \\
srGO (1 h) & $91.9 \%$ & $8.11 \%$ & 11.33 \\
srGO (2 h) & $89.78 \%$ & $8.49 \%$ & 10.57 \\
srGO (3 h) & $88.04 \%$ & $10.36 \%$ & 8.50 \\
\hline
\end{tabular}


We utilized the polyol method to synthesize Pt nanoparticles with rGO and various sizes of synthesized srGO supports, and X-ray diffraction (XRD) was performed to determine the effect of the crystalline structure of the Pt nanoparticles on the carbon support (Figure S2a). The XRD patterns of $\mathrm{Pt} / \mathrm{rGO}, \mathrm{Pt} / \mathrm{srGO}$, and $\mathrm{Pt} / \mathrm{C}$ were apparent on the (111), (200), and (220) planes of the face-centered cubic structure of crystalline Pt located at $2 \theta=40^{\circ}, 46^{\circ}$, and $68^{\circ}$ in all samples. Thermogravimetric analysis (TGA) was performed to assess the Pt content in the synthesized catalysts (Figure S2b). These results confirmed that all catalysts contained a consistent Pt content of $20 \mathrm{wt} \%$, indicating that the support activity could be compared to that of $\mathrm{Pt}$ of the same weight. The morphologies of the $\mathrm{Pt} / \mathrm{rGO}, \mathrm{Pt} / \mathrm{srGO}(1 \mathrm{~h}), \mathrm{Pt} / \mathrm{srGO}(2 \mathrm{~h})$, and $\mathrm{Pt} / \mathrm{srGO}(3 \mathrm{~h})$ catalysts were compared using TEM (Figure 4a-d). Representative TEM data collected for the Pt/rGO and Pt/srGO samples, as well as the histograms of these samples, were then evaluated. The size of the $\mathrm{Pt}$ nanoparticles depended on the size of the support. The average Pt particle size of sonicated rGO decreased from $4.3 \pm 1.8$ to $3.3 \pm 1.2,2.9 \pm 0.5$, and finally $2.0 \pm 0.5 \mathrm{~nm}$ after 1,2 , and $3 \mathrm{~h}$ of sonication, respectively. Several obvious agglomerations of Pt nanoparticles with an average size of $4.3 \mathrm{~nm}$ were found in $\mathrm{Pt} / \mathrm{rGO}$ (Figure 4a). In addition, greater aggregation was observed for the Pt/C catalyst (Figure S3). Comparisons of the catalysts with the same metal loading but with increased surface area of the support material revealed that the average particle size of $\mathrm{Pt}$ decreased, and the $\mathrm{Pt}$ size distribution became narrower. As the size of srGO decreased, the number of oxygen functional groups present in the defects increased, which resulted in an increase in the number of anchoring sites on the rGO surface and a decrease in the Pt nanoparticle size [33]. Therefore, we may infer that a smaller support material results in a narrower Pt size distribution and smaller Pt nanoparticles.

(a)

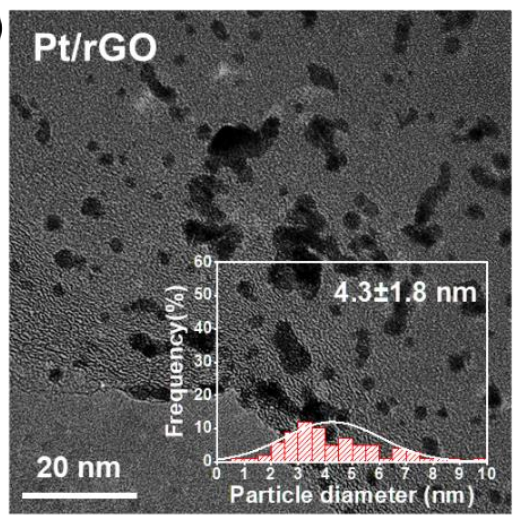

(c)

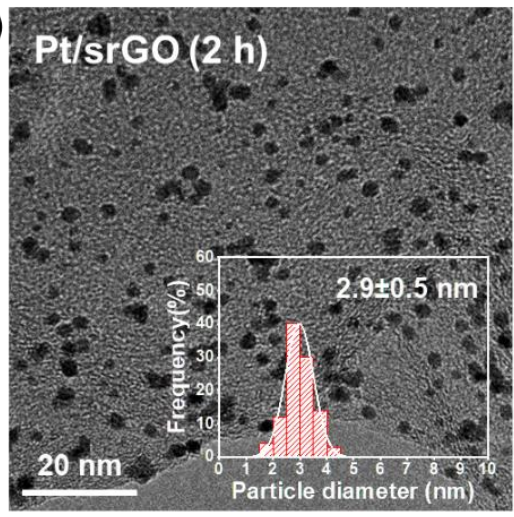

(b)

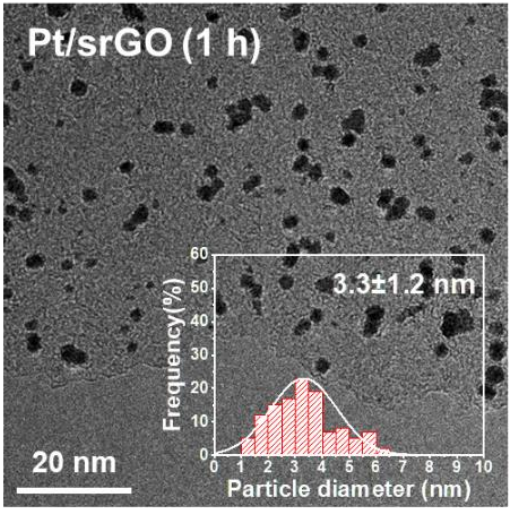

(d)

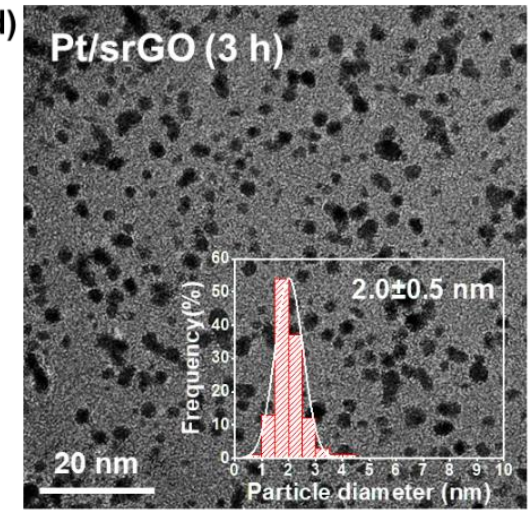

Figure 4. TEM images and corresponding Pt particle size distribution histograms of (a) Pt/rGO, (b) $\mathrm{Pt} / \mathrm{srGO}$ (1 h), (c) Pt/srGO (2 h), and (d) Pt/srGO (3 h).

To evaluate the fuel cell performance, we conducted linear sweep voltammetry (LSV) and cyclic voltammetry (CV) measurements. Figure 5a shows the typical CV curves of $\mathrm{Pt} / \mathrm{C}, \mathrm{Pt} / \mathrm{rGO}$, and $\mathrm{Pt} / \mathrm{srGO}(2 \mathrm{~h})$, which all exhibit a large cathodic peak at $0.55 \mathrm{~V}$ when 
an $\mathrm{O}_{2}$-saturated $0.5 \mathrm{M} \mathrm{H}_{2} \mathrm{SO}_{4}$ solution was the electrolyte; however, this peak was not observed in the $\mathrm{N}_{2}$-saturated electrolytes. Figure $5 \mathrm{~b}$ shows $\mathrm{CV}$ curves of the $\mathrm{Pt} / \mathrm{rGO}$, $\mathrm{Pt} / \mathrm{srGO}$, and $\mathrm{Pt} / \mathrm{C}$ catalysts, which all consisted of two regions: hydrogen desorption over the range of -0.2 to $0.15 \mathrm{~V}$ vs. $\mathrm{Ag} / \mathrm{AgCl}$ and double layer charging/discharging over the range of 0.15 to $4.0 \mathrm{~V}$ vs. $\mathrm{Ag} / \mathrm{AgCl}$ [34]. These electrolytes were mixed with $99.99 \%$ high-purity bubbling $\mathrm{N}_{2}$ for $30 \mathrm{~min}$ to eliminate $\mathrm{O}_{2}$. No significant ORR was observed in the $\mathrm{N}_{2}$-saturated electrolytes for all catalysts; however, the ORR was clearly observed with the $\mathrm{O}_{2}$-saturated electrolytes (Figure S4a). The electrochemical surface area (ECSA, $\mathrm{m}^{2} / \mathrm{g}_{\mathrm{Pt}}$ ) for hydrogen adsorption can be calculated using the CV curve (Figure 5b), as shown in Equation (1):

$$
\mathrm{ECSA}=\frac{\mathrm{S}}{2.1 \times \mathrm{V} \times \mathrm{M}^{\prime}}
$$

where $\mathrm{V}$ is the scan rate $(\mathrm{V} / \mathrm{s}), \mathrm{S}$ represents the integral area between the current and voltage in the hydrogen adsorption area $(\mathrm{mA} \cdot \mathrm{V})$, and $\mathrm{M}$ is the $\mathrm{Pt}$ load $(\mathrm{mg})$. We obtained the ECSAs for the catalysts: Pt/C, Pt/rGO, Pt/srGO (1 h), Pt/srGO (2 h), and Pt/srGO (3 h) (Table 3). Of all the catalysts, $\mathrm{Pt} / \mathrm{C}$ and $\mathrm{Pt} / \mathrm{rGO}$ exhibited the lowest ECSAs. Furthermore, for $\mathrm{Pt} / \mathrm{srGO}$, the ECSA gradually increased with sonication time. These results clearly show that the size of the Pt nanoparticles decreases, and the areal density increases with the increase in sonication time. The double-layer region mainly reflects the characteristics of srGO, and the current density in the double-layer region increased with sonication time due to the increase in the srGO surface area. Figure $5 \mathrm{c}$ shows the polarization curves of $\mathrm{Pt} / \mathrm{rGO}, \mathrm{Pt} / \mathrm{srGO}$, and $\mathrm{Pt} / \mathrm{C}$ at a rotation speed of $1600 \mathrm{rpm}$. It can be seen that $\mathrm{Pt} / \mathrm{srGO}(2 \mathrm{~h}$ ) exhibited a much better onset potential of $575.8 \mathrm{mV}$ vs. $\mathrm{Ag} / \mathrm{AgCl}$ than $\mathrm{Pt} / \mathrm{rGO}, \mathrm{Pt} / \mathrm{srGO}(1 \mathrm{~h}), \mathrm{Pt} / \mathrm{srGO}$ (3 h), and Pt/C (Figure S4b). Furthermore, the half-wave potential (E1/2) of $\mathrm{Pt} / \mathrm{srGO}(2 \mathrm{~h})$ was larger than those of $\mathrm{Pt} / \mathrm{srGO}(3 \mathrm{~h}), \mathrm{Pt} / \mathrm{srGO}(1 \mathrm{~h})$, $\mathrm{Pt} / \mathrm{rGO}$, and $\mathrm{Pt} / \mathrm{C}$. Owing to the high electroconductivity and specific area of $\mathrm{rGO}$, the electrochemical properties of $\mathrm{Pt} / \mathrm{rGO}$ and $\mathrm{Pt} / \mathrm{srGO}$ were better than those of $\mathrm{Pt} / \mathrm{C}$. In addition, we confirmed through the $\mathrm{CV}$ curves that a longer sonication time resulted in a larger specific surface area, higher ESCA, and higher current density. Especially, the decrease of catalyst size can increase the active surface area of catalyst particles, which greatly enhanced the ESCA and current density. However, the current density decreased with sonication times longer than $2 \mathrm{~h}$, which indicates that the smaller the size of rGO, the lower its overall electrical conductivity. As shown in Figure 3, the crystallinity of srGO $(3 \mathrm{~h})$ is reduced due to excessive surface defects. This results in low electrical conductivity, cannot sufficiently transfer the electrons generated in the electrochemical reaction, thus causing a significant decrease in the efficiency of the catalyst. Therefore, it can be confirmed that too many surface defects are generated in graphene as a result of increased sonication time, which reduces the crystallinity of graphene and the ORR characteristics. We determined the mass activity (MA) and specific activity (SA) of the catalysts to be $0.4 \mathrm{~V}$ (vs. Ag/ AgCl) based on their LSV curves. The reaction current at $0.4 \mathrm{~V}$ was divided by the true surface area and the actual mass of $\mathrm{Pt}$ to obtain the SA. The reaction current at $0.4 \mathrm{~V}$ was then divided by the actual mass of Pt to obtain the MA. The SA was calculated using Equation (2) as follows:

$$
\mathrm{SA}=\frac{\mathrm{I}}{\mathrm{ECSA} \times \mathrm{Pt}_{\text {Loading }}}
$$


(a)

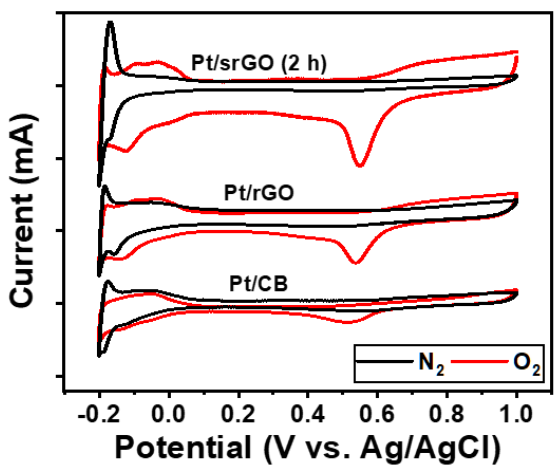

(c)

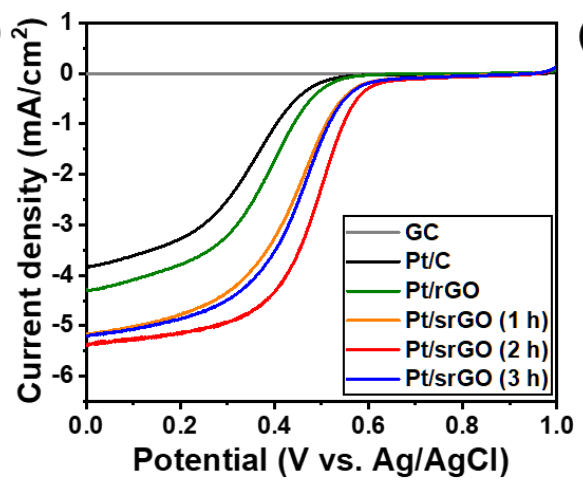

(b)

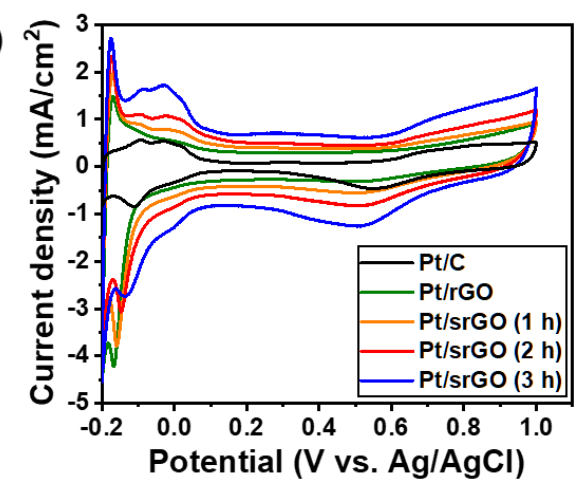

(d)

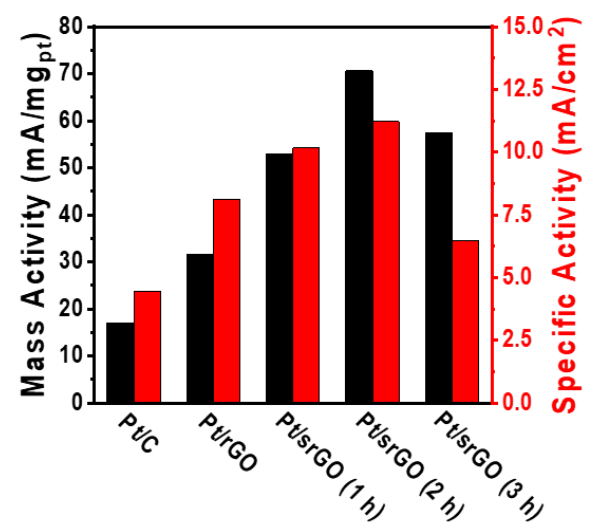

Figure 5. (a) CV curves of $\mathrm{Pt} / \mathrm{rGO}, \mathrm{Pt} / \mathrm{srGO}\left(2 \mathrm{~h}\right.$ ), and $\mathrm{Pt} / \mathrm{C}$ in $\mathrm{N}_{2}$-saturated (black lines) and $\mathrm{O}_{2}$-saturated (red lines) $0.5 \mathrm{M}$ $\mathrm{H}_{2} \mathrm{SO}_{4}$ at a scan rate of $20 \mathrm{mV} / \mathrm{s}$. (b) CV curves of the catalysts in $\mathrm{N}_{2}$-saturated $0.5 \mathrm{M} \mathrm{H}_{2} \mathrm{SO}_{4}$ at a scan rate of $20 \mathrm{mV} / \mathrm{s}$. (c) Polarization curves of that catalysts in $\mathrm{O}_{2}$-saturated $0.5 \mathrm{M} \mathrm{H}_{2} \mathrm{SO}_{4}$ at a scan rate of $5 \mathrm{mV} / \mathrm{s}$ and GCE rotational speed of $1600 \mathrm{rpm}$. (d) Mass and specific activities of the catalysts at $0.4 \mathrm{~V}$ vs. $\mathrm{Ag} / \mathrm{AgCl}$.

Table 3. ECSA, $E_{\text {onset }}, E_{\text {half-wave, }}$ Ma and SA of the catalysts.

\begin{tabular}{cccccc}
\hline Sample & $\begin{array}{c}\text { ECSA } \\
\left(\mathbf{m}^{\mathbf{2}} / \mathbf{g}_{\mathbf{P t}}\right)\end{array}$ & $\begin{array}{c}\mathbf{E}_{\text {onset }} \\
(\mathbf{m V})\end{array}$ & $\begin{array}{c}\mathbf{E}_{\text {half-wave }} \\
(\mathbf{m V})\end{array}$ & $\begin{array}{c}\mathbf{M A} \\
\left(\mathbf{m A} / \mathbf{m g}_{\mathbf{p t}}\right)\end{array}$ & $\begin{array}{c}\mathbf{S A} \\
\left(\mathbf{m A} / \mathbf{c m}^{\mathbf{2}}\right)\end{array}$ \\
\hline $\mathrm{Pt} / \mathrm{C}$ & 38.78 & 467.9 & 368.9 & 17.1 & 2.25 \\
$\mathrm{Pt} / \mathrm{rGO}$ & 39.48 & 493.8 & 399.8 & 31.7 & 4.09 \\
$\mathrm{Pt} / \mathrm{srGO}(1 \mathrm{~h})$ & 52.82 & 548.0 & 457.8 & 53.1 & 5.12 \\
$\mathrm{Pt} / \mathrm{srGO}(2 \mathrm{~h})$ & 63.69 & 575.8 & 497.8 & 70.6 & 5.66 \\
$\mathrm{Pt} / \mathrm{srGO}(3 \mathrm{~h})$ & 89.88 & 552.8 & 466.9 & 57.4 & 3.25 \\
\hline
\end{tabular}

Here, $\mathrm{Pt}_{\text {Loading }}$ represents the loading of the catalyst electrode $(\mathrm{mg})$. The MA was calculated using Equation (3), as shown below:

$$
\mathrm{MA}=\frac{\mathrm{I}}{\mathrm{Pt}_{\text {Loading }}}
$$

Here, I is the reaction current in the LSV curve at $0.4 \mathrm{~V}$ (MA).

The MA and SA shown in Figure $5 \mathrm{~d}$ were obtained by synchronizing the kinetic current with the mass of $\mathrm{Pt}$ and ECSA, respectively. The Pt/srGO (2 h) sample exhibited the best ORR performance with an MA and SA. For comparison, the respective MA and $\mathrm{SA}$ of $\mathrm{Pt} / \mathrm{srGO}(3 \mathrm{~h}), \mathrm{Pt} / \mathrm{srGO}(1 \mathrm{~h}), \mathrm{Pt} / \mathrm{rGO}$ and $\mathrm{Pt} / \mathrm{C}$. Therefore, the optimum conditions for producing a support material with a high specific surface area, low electrical resistance, and high ORR properties are found in graphene treated with hydrochloric acid for $2 \mathrm{~h}$.

The stabilities of $\mathrm{Pt} / \mathrm{CB}, \mathrm{Pt} / \mathrm{srGO}(2 \mathrm{~h})$, and $\mathrm{Pt} / \mathrm{srGO}(3 \mathrm{~h})$ were assessed by performing 1000 cycles of accelerated durability tests (ADTs) from -0.2 to $1.0 \mathrm{~V}$ vs. $\mathrm{Ag} / \mathrm{AgCl}$. The CV curves were measured in an $\mathrm{N}_{2}$-saturated $0.5 \mathrm{M} \mathrm{H}_{2} \mathrm{SO}_{4}$ solution at a scan rate of $50 \mathrm{mV} / \mathrm{s}$ 
before and after the ADT cycles, as shown in Figure 6a. The ECSA was calculated by measuring the coulombic charge for hydrogen desorption in the range of 0.2 to $1.0 \mathrm{~V}$ vs. $\mathrm{Ag} / \mathrm{AgCl}$. The normalized ESCA, which was evaluated after every 100 cycles, is shown in Figure $6 \mathrm{~b}$. The ECSA of Pt/srGO ( $2 \mathrm{~h}$ ) decreased by $21.1 \%$ after 1000 cycles of ADTs, which is less of a decrease than those observed in the ECSAs of Pt/srGO $(3 \mathrm{~h})(31.6 \%)$ and $\mathrm{Pt} / \mathrm{C}(57.6 \%)$. The polarization curves of $\mathrm{Pt} / \mathrm{srGO}(2 \mathrm{~h}), \mathrm{Pt} / \mathrm{srGO}(3 \mathrm{~h})$, and $\mathrm{Pt} / \mathrm{C}$ after 1000 cycles of ADTs are also shown in Figure 6c. The loss of the onset potential of Pt/srGO $(2 \mathrm{~h})$ was only $3.8 \mathrm{mV}$, which is much better than the losses noted for Pt/srGO $(9.8 \mathrm{mV})$ and $\mathrm{Pt} / \mathrm{C}(68 \mathrm{mV})$. A slightly negative shift of only $16.9 \mathrm{mV}$ (indicating only a $3.39 \%$ loss) was observed in the half-wave potential of $\mathrm{Pt} / \mathrm{srGO}(2 \mathrm{~h})$, making this catalyst more effective than $\mathrm{Pt} / \mathrm{srGO}(3 \mathrm{~h})$ and $\mathrm{Pt} / \mathrm{C}$ whose half-wave potentials negatively shifted by $28.1 \mathrm{mV}$ (indicating a $6.02 \%$ loss) and $90.1 \mathrm{mV}$ (indicating a $24.4 \%$ loss), respectively. Furthermore, the $\mathrm{Pt} / \mathrm{srGO}(2 \mathrm{~h})$ catalyst experienced a significant decrease in terms of its ESCA, MA, and SA (Figure $6 \mathrm{~d} \&$ Table 4 ).

(a)

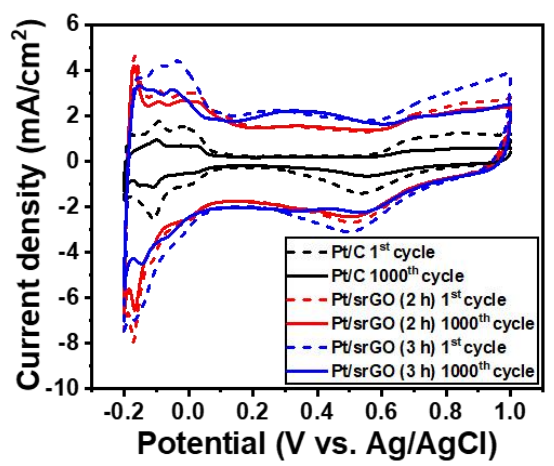

(c)

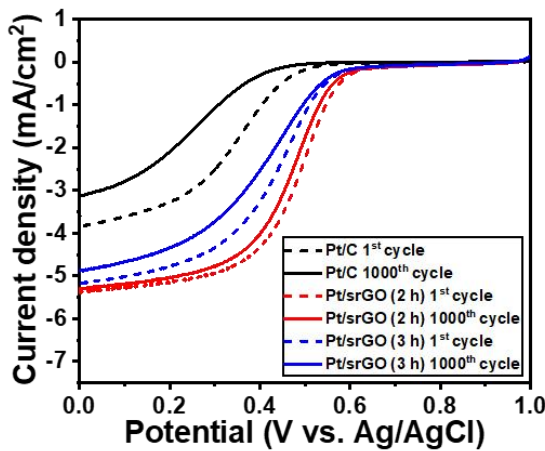

(e)

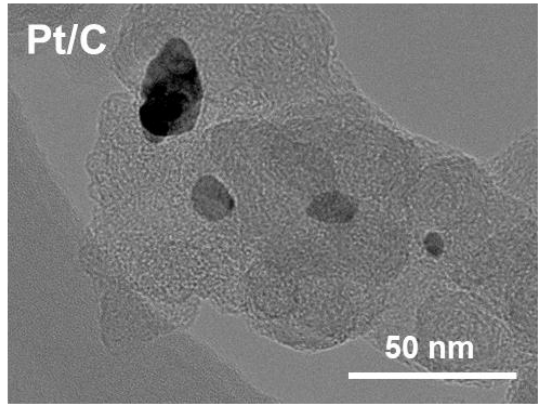

(b)

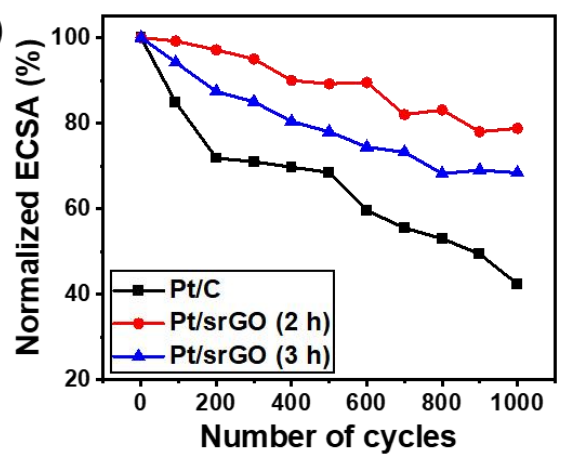

(d)
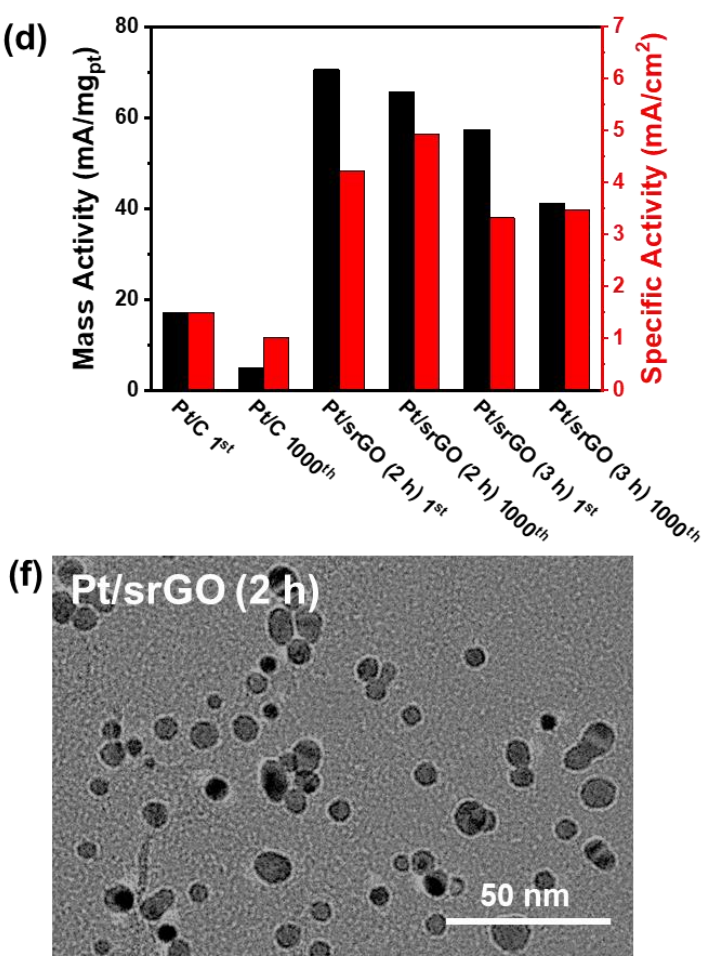

Figure 6. (a) $\mathrm{CV}$ curves of $\mathrm{Pt} / \mathrm{srGO}(2 \mathrm{~h}), \mathrm{Pt} / \mathrm{srGO}(3 \mathrm{~h})$, and $\mathrm{Pt} / \mathrm{C}$ before and after the ADTs for 1000 cycles in $\mathrm{N}_{2}$-saturated $0.5 \mathrm{M} \mathrm{H}_{2} \mathrm{SO}_{4}$ at a scan rate of $50 \mathrm{mV} / \mathrm{s}$. (b) ECSAs of the samples over 1000 electrochemical cycles. (c) Polarization CV curves of samples before and after ADTs for 1000 cycles in $\mathrm{O}_{2}$-saturated $0.5 \mathrm{M} \mathrm{H}_{2} \mathrm{SO}_{4}$ at a scan rate of $5 \mathrm{mV} / \mathrm{s}$ and GCE rotational speed of $1600 \mathrm{rpm}$. (d) Mass and specific activities of samples at $0.4 \mathrm{~V} \mathrm{vs}$. Ag/AgCl. TEM images of (e) Pt/C and (f) Pt/srGO (2 h) after ADTs for 1000 cycles. 
As previously stated, these data were obtained by synchronizing the kinetic current with the mass of $\mathrm{Pt}$ and ECSA. The MA of $\mathrm{Pt} / \mathrm{srGO}(2 \mathrm{~h})$ at $0.4 \mathrm{~V}$ vs. $\mathrm{Ag} / \mathrm{AgCl}$ reached $70.6 \mathrm{~mA} / \mathrm{mg}_{\mathrm{Pt}}$, which is much higher than those of $\mathrm{Pt} / \mathrm{srGO}(3 \mathrm{~h})$ and $\mathrm{Pt} / \mathrm{C}$. It should be noted that the loss of MA for Pt/srGO (2 h) was only $7.2 \%$ after 1000 cycles of ADTs at $0.4 \mathrm{~V}$ vs. $\mathrm{Ag} / \mathrm{AgCl}$, which was much lower than the losses observed for $\mathrm{Pt} / \mathrm{srGO}(3 \mathrm{~h})$ $(28.3 \%)$ and $\mathrm{Pt} / \mathrm{C}(71.2 \%)$. The $\mathrm{Pt} / \mathrm{srGO}(3 \mathrm{~h})$ catalyst caused a more significant decrease in the ESCA and ORR performance of the system than Pt/srGO $(2 \mathrm{~h})$ because the excessive surface defects of the former made srGO vulnerable to carbon oxidation reactions, and its particle bonding was relatively weak due to the presence of smaller particles. The $\mathrm{SA}$ of $\mathrm{Pt} / \mathrm{srGO}(2 \mathrm{~h})$ at $0.4 \mathrm{~V}$ vs. $\mathrm{Ag} / \mathrm{AgCl}$ was $2.13 \mathrm{~mA} / \mathrm{cm}^{2}$, which then increased to $2.49 \mathrm{~mA} / \mathrm{cm}^{2}$ after the ADTs. For comparison, the SA of Pt/srGO (3 h) $\left(1.67 \mathrm{~mA} / \mathrm{cm}^{2}\right)$ increased by a smaller amount to only $1.75 \mathrm{~mA} / \mathrm{cm}^{2}$. This is because the ECSA of Pt/srGO $(2 \mathrm{~h})$ showed less of a decrease than that of $\mathrm{Pt} / \mathrm{srGO}(3 \mathrm{~h})$. Additionally, the $\mathrm{SA}$ of $\mathrm{Pt} / \mathrm{C}$ $\left(0.75 \mathrm{~mA} / \mathrm{cm}^{2}\right)$ decreased to $0.51 \mathrm{~mA} / \mathrm{cm}^{2}$ because of the rapid decrease in current and its ECSA. The TEM images of Pt/srGO ( $2 \mathrm{~h})$ and $\mathrm{Pt} / \mathrm{C}$ were obtained before and after the ADTs. The Pt particles on commercial $\mathrm{Pt} / \mathrm{C}$ severely agglomerated into large, irregular nanoparticles after the ADTs, as shown in Figure 6e. However, the mean diameter of the $\mathrm{Pt}$ nanoparticles on $\mathrm{Pt} / \mathrm{srGO}(2 \mathrm{~h}$ ) exhibited less aggregation than those on $\mathrm{Pt} / \mathrm{C}$ after the ADTs, as shown in Figure 6e. Pt/srGO (2 h) was more stable than both Pt/srGO ( $3 \mathrm{~h}$ ) and $\mathrm{Pt} / \mathrm{C}$. The Pt/C catalyst experienced a significant decrease in ESCA following the ADTs, which was a result of the aggregation of the $\mathrm{Pt}$ nanoparticles due to the relatively corrosive nature of carbon [35]. Therefore, $\mathrm{Pt} / \mathrm{srGO}$ (2h) had the catalyst support with the most suitable defects and Pt nanoparticle size, providing it with the highest durability.

Table 4. ECSA, $\mathrm{E}_{\text {onset, }} \mathrm{E}_{\text {half-wave, }} \mathrm{MA}$ and SA change of the catalysts during durability analysis.

\begin{tabular}{|c|c|c|c|c|c|c|c|c|c|c|}
\hline \multirow[b]{2}{*}{ Sample } & \multicolumn{5}{|c|}{ As-Prepared } & \multicolumn{5}{|c|}{ After Durability Analysis } \\
\hline & $\begin{array}{c}\text { ECSA } \\
\left(\mathrm{m}^{2} / \mathrm{g}_{\mathrm{Pt}}\right)\end{array}$ & $\begin{array}{l}E_{\text {onset }} \\
(\mathrm{mV})\end{array}$ & $\begin{array}{c}E_{\text {half-wave }} \\
(\mathrm{mV})\end{array}$ & $\begin{array}{c}\text { MA } \\
\left(\mathrm{mA} / \mathrm{mg}_{\mathrm{pt}}\right)\end{array}$ & $\begin{array}{c}\mathrm{SA} \\
\left(\mathrm{mA} / \mathrm{cm}^{2}\right)\end{array}$ & $\begin{array}{c}\text { ECSA } \\
\left(\mathrm{m}^{2} / \mathrm{g}_{\mathrm{Pt}}\right)\end{array}$ & $\begin{array}{l}E_{\text {onset }} \\
(\mathrm{mV})\end{array}$ & $\begin{array}{c}\text { E }_{\text {half-wave }} \\
(\mathrm{mV})\end{array}$ & $\begin{array}{c}\mathrm{MA} \\
\left(\mathrm{mA} / \mathrm{mg}_{\mathrm{pt}}\right)\end{array}$ & $\begin{array}{c}\text { SA } \\
\left(\mathrm{mA} / \mathrm{cm}^{2}\right)\end{array}$ \\
\hline $\mathrm{Pt} / \mathrm{C}$ & 115.5 & 467.9 & 368.9 & 17.1 & 0.75 & 48.99 & 399.9 & 278.8 & 4.92 & 0.51 \\
\hline $\mathrm{Pt} / \operatorname{srGO}(2 \mathrm{~h})$ & 169.3 & 575.8 & 497.8 & 70.6 & 2.13 & 134.5 & 572.0 & 480.9 & 65.6 & 2.49 \\
\hline $\mathrm{Pt} / \mathrm{srGO}(3 \mathrm{~h})$ & 174.8 & 552.8 & 466.9 & 57.4 & 1.67 & 119.7 & 543.0 & 438.8 & 14.2 & 1.75 \\
\hline
\end{tabular}

\section{Materials and Methods}

\subsection{Controlling the Size of $r G O$}

rGO was obtained from Standard Graphene Inc., and strong sonication was used to control its size by breaking the weak carbon bonds at the sites of any defects. First, $150 \mathrm{mg}$ of $\mathrm{rGO}$ was mixed with $300 \mathrm{~mL}$ of $10 \mathrm{vol} \% \mathrm{HCl}$ and subjected to 1, 2, or $3 \mathrm{~h}$ of sonication. The synthesized srGO samples were then washed with ethanol and deionized water and placed in an oven at $100{ }^{\circ} \mathrm{C}$ overnight to dry.

\subsection{Synthesizing the Pt/rGO Catalysts}

Catalysts were synthesized via the polyol method using a microwave (Multiwave 5000, Anton Paar GmbH, Graz, Austria) and a fixed amount of Pt (20 wt\%). First, $80 \mathrm{mg}$ of rGO, srGO, and CB were mixed with $40 \mathrm{~mL}$ of ethyl glycol and sonicated for $1 \mathrm{~h}$. A $\mathrm{Pt}$ precursor, Chloroplatinic acid solution $\left(\mathrm{H}_{2} \mathrm{PtCl}_{6} \cdot 6 \mathrm{H} 2 \mathrm{O}\right.$ Sigma-Aldrich), was added to the solution using a magnetic stirrer for approximately $30 \mathrm{~min}$. The $\mathrm{pH}$ of the solution was adjusted to 12 using potassium hydroxide. The prepared solution was then heated in a microwave oven. The synthesized catalysts were washed with ethanol and deionized water and placed in a vacuum oven at $50{ }^{\circ} \mathrm{C}$ to dry overnight.

\subsection{Characterizing the Materials}

The surface morphologies and elemental compositions of the samples were analyzed using field-emission SEM (FE-SEM; Hitachi, Tokyo, Japan, SU8020) and TEM (JEOL Ltd., Tokyo, Japan, JEM-2100F). The chemical compositions and functional groups of rGO and 
srGO were examined via XPS (Thermo Scientific, Waltham, MA, USA, K Alpha+) analysis was then conducted using $\mathrm{Al}-\mathrm{K} \alpha$ radiation. The binding energy was normalized according to the position of the $C$ 1s peak as a result of the adsorbed hydrocarbon fragments. Raman spectroscopy (WITec, Ulm, Germany, alpha300s) was conducted to identify any changes in the defects within rGO and srGO using a DXR Raman microscope with incident light at a wavelength of $532 \mathrm{~nm}$. We analyzed the extent of crystallinity using XRD (Rigaku, Tokyo, Japan, Ultima IV / Rigaku) with $\mathrm{Cu} \mathrm{K} \alpha(\lambda=0.15406 \mathrm{~nm})$ radiation over the $2 \theta$ range of $10^{\circ}$ to $85^{\circ}$ at a scan rate of $1^{\circ} / \mathrm{min}$. The electrical characteristics of rGO and srGO were measured with a SMU (Keithley, Tektronix, 2400) in a pressure cell (M\&S Vacuum) under uniaxial pressure $(5 \mathrm{MPa})$ at room temperature. The Pt nanoparticle contents of the prepared catalysts were measured using TGA (Mettler Toledo, Greifensee, Switzerland, TGA/DSC1) under air flow at temperatures ranging from 3 to $200{ }^{\circ} \mathrm{C}$, which were maintained for $2 \mathrm{~h}$ and subsequently increased to $850^{\circ} \mathrm{C}$ at a rate of $10^{\circ} \mathrm{C} / \mathrm{min}$.

\subsection{Measuring the Electrochemical Properties}

Electrochemical measurements of the catalysts were performed using a half-cell system with three electrodes (BioLogic, Seyssinet-Pariset, France, VSP 300). A Pt wire and Ag/ $\mathrm{AgCl}$ electrode were used as the counter and reference electrodes, respectively. The catalyst was coated on the surface of glassy carbon (GC) (AFE5T050GC, $5.0 \mathrm{~mm}$ disk OD, Pine Research, Durham, USA) and used as the working electrode. To measure the electrochemical activity of the catalyst, approximately $5 \mathrm{mg}$ of a mixture containing IPA $(1 \mathrm{~mL})$ and $5 \mathrm{wt} \%$ Nafion solution $(60 \mu \mathrm{L})$ was added and sonicated for 30 min until a homogenous suspension was obtained. The GC electrode was prepared by drop-casting $20 \mathrm{uL}$ of this solution to obtain a catalytic suspension using a micropipette, followed by drying at $27^{\circ} \mathrm{C}$ for $20 \mathrm{~min}$. $\mathrm{CV}$ curves were measured at a scan rate of $20 \mathrm{mV} / \mathrm{s}$ within a range of -0.2 to $1.0 \mathrm{~V}$ in $\mathrm{N}_{2}$-saturated $0.5 \mathrm{M} \mathrm{H}_{2} \mathrm{SO}_{4}$. LSV measurements with a scan rate of $5 \mathrm{mV} / \mathrm{s}$ were obtained with $\mathrm{RDE}$ rotation rates of $1600 \mathrm{rpm}$ in $\mathrm{O}_{2}$-saturated $0.5 \mathrm{M} \mathrm{H}_{2} \mathrm{SO}_{4}$. ADTs were performed at a scan rate of $20 \mathrm{mV} / \mathrm{s}$ for 1000 cycles from 0.2 to $1.0 \mathrm{~V}$ vs. $\mathrm{Ag} / \mathrm{AgCl}$ in $0.5 \mathrm{M} \mathrm{H}_{2} \mathrm{SO}_{4}$.

\section{Conclusions}

We demonstrated highly efficient oxygen reduction catalysts composed of uniform $\mathrm{Pt}$ nanoparticles on srGO. The rGO size was controlled by applying a physical force via ultrasonication, where increased sonication times decreased the rGO size. The srGO enabled the morphological control of the Pt nanoparticles, and the resultant, prepared catalysts provided efficient surface reactions and exhibited large surface areas and high metal dispersions. The $\mathrm{Pt} / \mathrm{srGO}$ catalysts prepared with $2 \mathrm{~h}$ of sonication exhibited excellent oxygen reduction performances and high stability over 1000 cycles of ADTs. The detailed analysis of the structural and electrochemical properties of the resulting catalysts suggested that both the chemical functionality and electrical conductivity greatly contribute to their enhanced efficiency. We believe that our study will make a significant contribution to the currently existing literature and inspire future studies on the electrochemical applications of these materials owing to their versatility regarding various types of fuel cells.

Supplementary Materials: The following are available online at https://www.mdpi.com/article/10 .3390 /ijms222212300/s1, Figure S1: The C 1s region of the X-ray photoelectron spectroscopy (XPS) spectra. Figure S2: X-ray diffraction (XRD) patterns and thermogravimetric analysis (TGA) curves of the catalyst samples. Figure S3: Scanning electron microscopy (SEM) image of Pt/C. Figure S4: Cyclic voltammetry $(\mathrm{CV})$ curves of the catalyst samples and onset potentials in the polarization curves of the catalyst samples.

Author Contributions: S.-J.B. and S.-I.K. contributed to the work equally. Conceptualization, S.-H.K. and D.H.L.; methodology, S.-y.L. and T.K.; validation, writing-original draft preparation, S.-J.B. and S.-I.K.; writing-review and editing, S.-H.K. and D.H.L.; project administration, D.H.L. All authors have read and agreed to the published version of the manuscript. 
Funding: This research was funded by the Korea Institute of Industrial Technology (KITECH), grant number EI210023, and the Ministry of SMEs and Startups (MSS, Korea), grant number S2912921.

Institutional Review Board Statement: Not applicable.

Informed Consent Statement: Not applicable.

Data Availability Statement: The data that support the findings of this study are available from the corresponding authors upon reasonable request.

Conflicts of Interest: The authors declare no conflict of interest.

\section{References}

1. Cha, B.-C.; Jun, S.; Jeong, B.; Ezazi, M.; Kwon, G.; Kim, D.; Lee, D.H. Carbon nanotubes as durable catalyst supports for oxygen reduction electrode of proton exchange membrane fuel cells. J. Power Sources 2018, 401, 296-302. [CrossRef]

2. Sharma, S.; Pollet, B.G. Support materials for PEMFC and DMFC electrocatalysts-A review. J. Power Sources 2012, 208, 96-119. [CrossRef]

3. Lee, D.H.; Lee, W.J.; Kim, S.O.; Kim, Y.-H. Theory, Synthesis, and Oxygen Reduction Catalysis of Fe-Porphyrin-Like Carbon Nanotube. Phys. Rev. Lett. 2011, 106, 175502. [CrossRef] [PubMed]

4. Wu, J.; Yuan, X.Z.; Martin, J.J.; Wang, H.; Zhang, J.; Shen, J.; Wu, S.; Merida, W. A review of PEM fuel cell durability: Degradation mechanisms and mitigation strategies. J. Power Sources 2008, 184, 104-119. [CrossRef]

5. Service, R.F. Shrinking Fuel Cells Promise Power in Your Pocket. Science 2002, 296, 1222-1224. [CrossRef]

6. Okada, M.; Konta, Y.; Nakagawa, N. Carbon nano-fiber interlayer that provides high catalyst utilization in direct methanol fuel cell. J. Power Sources 2008, 185, 711-716. [CrossRef]

7. Kim, J.; Kim, S.-I.; Jo, S.G.; Hong, N.E.; Ye, B.; Lee, S.; Dow, H.S.; Lee, D.H.; Lee, J.W. Enhanced activity and durability of Pt nanoparticles supported on reduced graphene oxide for oxygen reduction catalysts of proton exchange membrane fuel cells. Catal. Today 2020, 352, 10-17. [CrossRef]

8. Li, Z.; Gao, Q.; Zhang, H.; Tian, W.; Tan, Y.; Qian, W.; Liu, Z. Low content Pt nanoparticles anchored on N-doped reduced graphene oxide with high and stable electrocatalytic activity for oxygen reduction reaction. Sci. Rep. 2017, 7, 43352. [CrossRef] [PubMed]

9. Lee, D.H.; Kim, J.E.; Han, T.H.; Hwang, J.W.; Jeon, S.; Choi, S.-Y.; Hong, S.H.; Lee, W.J.; Ruoff, R.S.; Kim, S.O. Versatile Carbon Hybrid Films Composed of Vertical Carbon Nanotubes Grown on Mechanically Compliant Graphene Films. Adv. Mater. 2010, 22, 1247-1252. [CrossRef]

10. Lee, S.H.; Lee, D.H.; Lee, W.J.; Kim, S.O. Tailored Assembly of Carbon Nanotubes and Graphene. Adv. Funct. Mater. 2011, 21, 1338-1354. [CrossRef]

11. Hong, J.-Y.; Lee, E.; Jang, J. Electro-responsive and dielectric characteristics of graphene sheets decorated with TiO2nanorods. J. Mater. Chem. A 2013, 1, 117-121. [CrossRef]

12. Yin, J.; Wang, X.; Chang, R.; Zhao, X. Polyaniline decorated graphene sheet suspension with enhanced electrorheology. Soft Matter 2012, 8, 294-297. [CrossRef]

13. Zhang, W.L.; Liu, Y.D.; Choi, H.J.; Kim, S.G. Electrorheology of Graphene Oxide. ACS Appl. Mater. Interfaces 2012, 4, $2267-2272$. [CrossRef] [PubMed]

14. Zhang, W.L.; Choi, H.J. Fast and Facile Fabrication of a Graphene Oxide/Titania Nanocomposite and Its Electro-Responsive Characteristics. Chem. Commun. 2011, 47, 12286-12288. [CrossRef]

15. He, D.; Cheng, K.; Peng, T.; Sun, X.; Pan, M.; Mu, S. Bifunctional effect of reduced graphene oxides to support active metal nanoparticles for oxygen reduction reaction and stability. J. Mater. Chem. 2012, 22, 21298-21304. [CrossRef]

16. Ye, B.; Lee, M.; Jeong, B.; Kim, J.; Lee, D.H.; Baik, J.M.; Kim, H.-D. Partially reduced graphene oxide as a support of Mn-Ce/TiO2 catalyst for selective catalytic reduction of NOx with NH3. Cat. Today 2019, 328, 300-306. [CrossRef]

17. Antolini, E. Graphene as a new carbon support for low-temperature fuel cell catalysts. Appl. Catal. B Environ. 2012, 123, 52-68. [CrossRef]

18. Lee, M.; Kim, S.-I.; Lee, M.-J.; Ye, B.; Kim, T.; Kim, H.-D.; Lee, J.; Lee, D. Effect of Catalyst Crystallinity on V-Based Selective Catalytic Reduction with Ammonia. Nanomaterials 2021, 11, 1452. [CrossRef]

19. Pushkareva, I.; Pushkarev, A.; Kalinichenko, V.; Chumakov, R.; Soloviev, M.; Liang, Y.; Millet, P.; Grigoriev, S. Reduced Graphene Oxide-Supported Pt-Based Catalysts for PEM Fuel Cells with Enhanced Activity and Stability. Catalysts 2021, 11, 256. [CrossRef]

20. Yadav, R.; Subhash, A.; Chemmenchery, N.; Kandasubramanian, B. Graphene and Graphene Oxide for Fuel Cell Technology. Ind. Eng. Chem. Res. 2018, 57, 9333-9350. [CrossRef]

21. He, D.; Kou, Z.; Xiong, Y.; Cheng, K.; Chen, X.; Pan, M.; Mu, S. Simultaneous sulfonation and reduction of graphene oxide as highly efficient supports for metal nanocatalysts. Carbon 2014, 66, 312-319. [CrossRef]

22. Baamran, K.S.; Tahir, M.; Mohamed, M.; Khoja, A.H. Effect of support size for stimulating hydrogen production in phenol steam reforming using Ni-embedded TiO2 nanocatalyst. J. Environ. Chem. Eng. 2020, 8, 103604. [CrossRef] 
23. Luo, S.; Barrio, L.; Nguyen-Phan, T.-D.; Vovchok, D.; Johnston-Peck, A.C.; Xu, W.; Stach, E.A.; Rodriguez, J.A.; Senanayake, S.D. Importance of Low Dimensional CeOx Nanostructures in $\mathrm{Pt} / \mathrm{CeOx}-\mathrm{TiO}_{2}$ Catalysts for the Water-Gas Shift Reaction. J. Phys. Chem. C 2017, 121, 6635-6642. [CrossRef]

24. Ferencz, Z.; Erdohelyi, A.; Baán, K.; Oszkó, A.; Óvári, L.; Kónya, Z.; Papp, C.; Steinruck, H.-P.; Kiss, J. Effects of support and Rh additive on Co-based catalysts in the ethanol steam reforming reaction. ACS Catal. 2014, 4, 1205-1218. [CrossRef]

25. Kočí, K.; Obalová, L.; Matějová, L.; Plachá, D.; Lacný, Z.; Jirkovský, J.; Solcova, O. Effect of $\mathrm{TiO}_{2}$ particle size on the photocatalytic reduction of $\mathrm{CO}_{2}$. Appl. Catal. B 2009, 89, 494-502. [CrossRef]

26. Soykal, I.I.; Sohn, H.; Ozkan, U.S. Effect of Support Particle Size in Steam Reforming of Ethanol over Co/CeO 2 Catalysts. ACS Catal. 2012, 2, 2335-2348. [CrossRef]

27. Haga, F.; Nakajima, T.; Yamashita, K.; Mishima, S. Effect of particle size on steam reforming of ethanol over alumina-supported cobalt catalyst. Nippon. Kagaku Kaishi 1997, 11, 758-762. [CrossRef]

28. Aramouni, N.A.K.; Zeaiter, J.; Kwapinski, W.; Ahmad, M.N. Thermodynamic analysis of methane dry reforming: Effect of the catalyst particle size on carbon formation. Energy Convers. Manag. 2017, 150, 614-622. [CrossRef]

29. Malard, L.M.; Pimenta, M.A.; Dresselhaus, G.; Dresselhaus, M.S. Raman spectroscopy in graphene. Phys. Rep. 2009, 473, 51-87. [CrossRef]

30. Ye, B.; Kim, S.-I.; Lee, M.; Ezazi, M.; Kim, H.-D.; Kwon, G.; Lee, D.H. Synthesis of oxygen functionalized carbon nanotubes and their application for selective catalytic reduction of NOx with NH3. RSC Adv. 2020, 10, 16700-16708. [CrossRef]

31. Shin, K.-Y.; Hong, J.-Y.; Lee, S.; Jang, J. Evaluation of anti-scratch properties of graphene oxide/polypropylene nanocomposites. J. Mater. Chem. 2012, 22, 7871-7879. [CrossRef]

32. Shin, K.-Y.; Lee, S.; Hong, S.; Jang, J. Graphene Size Control via a Mechanochemical Method and Electro-Responsive Properties. ACS Appl. Mater. Interfaces 2014, 6, 5531-5537. [CrossRef] [PubMed]

33. Eslava, J.L.; Sun, X.; Gascon, J.; Kapteijn, F.; Rodríguez-Ramos, I. Ruthenium particle size and cesium promotion effects in Fischer-Tropsch synthesis over high-surface-area graphite supported catalysts. Catal. Sci. Technol. 2017, 7, 1235-1244. [CrossRef]

34. Guo, S.; Zhang, S.; Su, D.; Sun, S. Seed-mediated synthesis of core/shell FePtM/FePt (M = Pd, Au) nanowires and their electrocatalysis for oxygen reduction reaction. J. Am. Chem. Soc. 2013, 135, 13879-13884. [CrossRef] [PubMed]

35. Guo, L.; Jiang, W.-J.; Zhang, Y.; Hu, J.-S.; Wei, Z.-D.; Wan, L.-J. Embedding Pt Nanocrystals in N-Doped Porous Carbon/Carbon Nanotubes toward Highly Stable Electrocatalysts for the Oxygen Reduction Reaction. ACS Catal. 2015, 5, 2903-2909. [CrossRef] 